\title{
Zilrotakalle
}

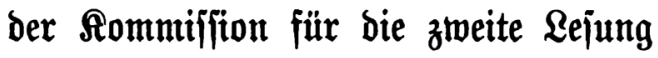

ธeติ

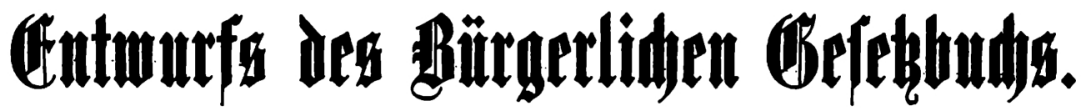

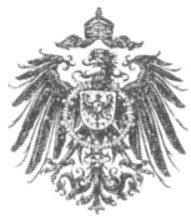

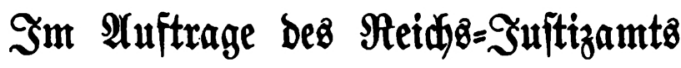

bearbeitet von

Dr. Xdille

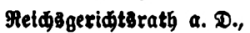

Dr. Belugaxd,

Dr. Epaba,

Erofí. bab. Begeimer Math,

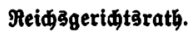

\section{Bamb II.}

Redt ber Sduldverhältniffe

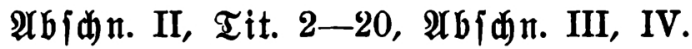

Berlin SW

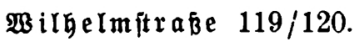

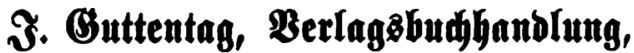

(5). m. b. $\mathfrak{D}$. 
Drud ber Morbbeutiden Bubbruderet, Bexlin sw. 